\title{
ASSOCIATION BETWEEN PRE-POST OPERATIVE PROCEDURE AND ABDOMINAL SURGICAL INFECTION
}

\author{
Aplonia Farida Djami, Aloysius Liliweri, Sabina Gero \\ Masters Program in Public Health, Universitas Nusa Cendana, Kupang
}

\begin{abstract}
Background: Surgical wound infection remains an important problem following an operation. The risk of such infections is determined by technical problems with the operation, such of bleeding, the amount of devitalized tissue created, and the need for drains within the wound, as well as such metabolic factors as obesity and diabetes. Pre-operative preparation is vital to patient safety and a key nursing role. Perioperative antibiotic prophylaxis can decrease the incidence of such infections, but a technically perfect operation is even more important. This study aimed to determine the association between pre-post operative procedure and abdominal surgical infection.

Subjects and Method: This was a cohort study carried out in Kupang, East Nusa Tenggara. A sample of 62 patients were selected for this study. The dependent variable was abdominal surgical infection. The independent variable was pre-post operative procedure, including surgical preparation and wound technique. Abdominal surgical infection was measured by observation. The other data were collected from medical record. The data were analyzed by chi-square test and Prevalence Ratio (PR) as the measure of association.

Results: Prevalence of abdominal surgical infection was $14.5 \%$. Of the total number of infection, $77.8 \%$ arose from caesarean section. The risk of post surgical infection increased with inappropriate surgical preparation a day before surgery $(\mathrm{PR}=$ 6.00; $\mathrm{p}=0.010)$ and inappropriate wound technique $(\mathrm{PR}=4.71 ; \mathrm{p}=0.140)$.

Conclusion: The highest prevalence of abdominal surgical infection arises from caesarian section. There is a relationship between incorrect pre-operation procedure and incorrect wound technique with the risk of post-surgical infection.
\end{abstract}

Keywords: infection, abdominal surgical, caesarian section, pre-post operative procedure

Correspondence:

Aplonia Farida Djami. Masters Program in Public Health, Universitas Nusa Cendana, Kupang, East Nusa Tenggara. Email: idadjami@gmail.com.

Mobile: 081237717140.

The 4th International Conference on Public Health Best Western Premier Hotel, Solo, Indonesia, August 29-30, 2018 | 304 https://doi.org/10.26911/theicph.2018.05.19 